\section{Efficacy of Horticultural Oil and Insecticidal Soap against Selected Armored and Soft Scales}

\author{
Carlos R. Quesada ${ }^{1}$ and Clifford S. Sadof
}

ADDITIONAL INDEX WORDs. integrated pest management, scale insects, Chionaspis pinifoliae, Aspidiotus nerii, Toumeylla pini, Eulecanium cerasorium

SUMMARY. Insecticidal soap and horticultural oil have the potential to kill individuals within populations of soft-bodied insect pests by suffocation. However, scientific literature is inconsistent about the efficacy of insecticidal soaps and petroleum-based oils against armored scale (Hemiptera: Diaspidae) and soft scale (Hemiptera: Coccidae). We examined the efficacy of horticultural oil and insecticidal soap against armored and soft scales at different developmental life stages. Studies were conducted in the laboratory and field with two species of armored scale [pine needle scale (Chionaspis pinifoliae) and oleander scale (Aspidiotus nevii)] and two species of soft scale [calico scale (Eulecanium cerasorium) and striped pine scale (Toumeylla pini)]. All insecticide applications were made at a rate of 2 gal per 100 gal water. Our laboratory results suggested that horticultural oil and insecticidal soap killed both calico scale ( $73 \%$ and $93 \%$, respectively) and oleander scale ( $67 \%$ and $78 \%$, respectively) when insecticides targeted 1-day-old scales. Scale insects built up tolerance to both materials over time after they settled. However, our field data indicated that horticultural oil had high control of settled armored scale [oleander scale $(90 \%)$ and pine needle scale $(83 \%)$ ], but failed to control settled soft scale [stripe pine scale $(5 \%)$ ]. Insecticidal soap reduced armored scale [oleander scale $(54 \%)]$. Neither horticultural oil nor insecticidal soap significantly reduced populations of adult armored or soft scales compared with a control. Overall, horticultural oil killed a greater percentage of armored scales than soft scales, whereas insecticidal soap gave greater control against soft scales. We suggest that differences were driven by chemical properties of both insect integuments and insecticides. The waxy cover of an armored scale might reduce penetration of polar insecticidal soap whereas polar integument of a soft scale might impede infiltration of the lipophilic horticultural oil. Consequently, timing application to crawler stage is important for effective management of armored or soft scale with horticultural oils and insecticidal soaps.

$\mathrm{I}$ nsecticidal soap and horticultural oil have been used since the late 1800s to manage soft-bodied insect pests of fruits, shade trees, and ornamental plants (Weinzierl, 2000). Insecticidal soaps are made of a potassium salt of a plant-derived fatty acid with long carbon chains (Weinzierl, 2000; Yu, 2015). Horticultural oils have a narrow distillation range that allows them to be applied on leaves with reduced phytotoxic effects (Agnello,

Department of Entomology, Purdue University, 901 West State Street, West Lafayette, IN 47907.

We thank D. Richmond, M. Scharf, and R. Lopez, for their comments on this manuscript. We also thank A. Caballero and A. Rios for their help in the field and laboratory, and J. O'Donnell for providing a source of pine needle scale materials. The research was conducted in partial fulfillment of the requirements for PhD to C. Quesada who was supported by USDA APHIS Cooperative Agreement 08-8218-0520-CA awarded to C. Sadof.

${ }^{1}$ Corresponding author. E-mail: cquesand@purdue. edu.

doi: 10.21273/HORTTECH03752-17
2002; Cranshaw and Baxendale, 2005; Weinzierl, 2000). Both oil and soap can kill natural enemies on contact (Bostanian and Akalach, 2004, 2006; Oetting and Latimer, 1995; Smith and Krischik, 2000). Nevertheless these materials are commonly used to manage scale insects (Hemiptera: Coccoidea) in integrated pest management (IPM) programs because of their short-term residual toxicity (Gill and Raupp, 1989; Miller, 1989; Miller and Davidson, 2005; Raupp et al., 2001; Sadof and Sclar, 2000).

Horticultural oil blocks the spiracles necessary for gas exchange and can asphyxiate an insect when carbon dioxide and other toxins accumulate to toxic levels (Yu, 2015). In addition, oils can combine with the fatty acids within the insect body to interfere with normal metabolism and destroy membranes, particularly of immature insects (Ebeling, 1936; Miller, 1989; Phillips and Smith, 1963). Similarly, insecticidal soap induces mortality by penetrating the insect's body and disrupting the normal function of cells and membranes and causing asphyxia (Cating et al., 2010; Koehler et al., 1983; Miller, 1989; Tremblay et al., 2008).

Despite incorporation of oils and insecticidal soaps in IPM programs, there is conflicting information in the scientific literature as to whether oils or soaps can reduce population of soft and armored scales in a consistent manner. Numerous studies on armored scale insects have shown that horticultural oils consistently provide at least $85 \%$ reduction in scale populations (Frank, 2012; Hollingsworth, 2005; Pless et al., 1995; Raupp et al., 2001; Sadof and Sclar, 2000; Xiao et al., 2016). However, other studies have shown less than $50 \%$ control with horticultural oils and insecticidal soaps for soft scale (Dreistadt, 1996; Grafton-Cardwell and Reagan, 1999; Hubbard and Potter, 2006; Phillips and Smith, 1963; Pless et al., 1995; Reinking, 1964) and armored scale (Addesso et al., 2016a, 2016b; Caldwell, 2003; Heller et al., 2004; Rebek and Sadof, 2003).

The life history of scale insects can make timing of application and insect stage important determinants of efficacy of oils and insecticidal soaps (Hubbard and Potter, 2006; Raupp et al., 2001; Sadof and Sclar, 2000). During egg production, adult armored and soft scales are sessile. Eggs are laid under the waxy cover of an armored scale or under the body of a soft scale. These hatch into a mobile dispersal stage called a crawler that can walk or be blown by the wind.

\begin{tabular}{llll}
\hline $\begin{array}{l}\text { Units } \\
\text { To convert U.S. to SI, } \\
\text { multiply by }\end{array}$ & U.S. unit & SI unit & $\begin{array}{l}\text { To convert SI to U.S., } \\
\text { multiply by }\end{array}$ \\
\hline 29.5735 & $\mathrm{fl} \mathrm{oz}$ & $\mathrm{mL}$ & 0.0338 \\
0.3048 & $\mathrm{ft}$ & $\mathrm{m}$ & 3.2808 \\
3.7854 & gal & $\mathrm{L}$ & 0.2642 \\
2.54 & inch(es) & $\mathrm{cm}$ & 0.3937 \\
$\left({ }^{\circ} \mathrm{F}-32\right) \div 1.8$ & ${ }^{\circ} \mathrm{F}$ & ${ }^{\circ} \mathrm{C}$ & $\left({ }^{\circ} \mathrm{C} \times 1.8\right)+32$
\end{tabular}


Once armored scale insects find a suitable place to feed, they settle and stay in that location until adult winged males emerge or until adult females die (Rosen, 1990). Armored scale insects are characterized by their waxy cover, often called a test, which forms 24 to $48 \mathrm{~h}$ after they settled and encloses the top of their body (Miller and Davidson, 2005; Rosen, 1990). Covers of armored scales are made of wax, proteins, and old cast skins (exuviae) (Rosen, 1990). For example, california red scale (Aonidiella aurantii) is composed of $45 \%$ waxes, $47 \%$ proteins, and $8 \%$ of exuviae (Dickson, 1951). These proteins are amphipathic molecules that contain hydrophilic and hydrophobic fragments. In contrast, waxes are composed of only a long-chain fatty acid bonded to a long-chain alcohol group. Because of their nonpolar carbon chains, waxes are extremely hydrophobic (Ben-Dov and Hodgson, 1997; Hackman, 1951; Sewald and Jakubke, 2002).

Some families of soft scale insects retain functioning legs, so they can move to different parts of their host plant to complete their life cycle (Ben-Dov and Hodgson, 1997; Kosztarab, 1996). For example, calico scales feed on leaves during the summer and move to the bark early in the fall where they complete their life cycle (Hubbard and Potter, 2005). However, other species, such as striped pine scale, remain where they settle much like armored scales (Clarke et al., 1989). Soft scales produce honeydew from a pair of triangular plates at their posterior. Honeydew is composed mostly of sugars and amino acids (Ben-Dov and Hodgson, 1997; Leroy et al., 2011; Völkl et al., 1999; Woodring et al., 2004). Wax is secreted from the epidermal cells onto the outer surface through the pore canals which form a bulky wax cover over insect bodies. Unlike armored scales, wax content of soft scales is relatively low (Ben-Dov and Hodgson, 1997; Hackman, 1951; Tamaki and Kawai, 1969). For instance, the body weight of white wax scale (Ceroplastes destructor) is made of $13 \%$ wax, $86 \%$ honeydew, and $1 \%$ integument (Hackman, 1951). Covers form by indian wax scale (Ceroplastes pseudoceriferus) contain about 16\% true wax (Hashimoto et al., 1967).

We hypothesized that horticultural oil and insecticidal soap would have different efficacy against armored and soft scales because of the presence or absence of a waxy cover. $\mathrm{Yu}$ (2015) reported that the rate of penetration of liposoluble insecticides correlated with the amount of lipid in the insect integument. We used two species of each armored and soft scale for this study.

Pine needle scale is an armored scale that has two generations per year in the midwestern United States (Philpott et al., 2009; Shour and Schuder, 1987). They usually overwinter as eggs on the needles but may also winter as mated adult females. The first generation hatches from overwintering eggs in May or eggs laid by overwintering females in June (Katovich et al., 2014; Rosen, 1990; Shour and Schuder, 1987). Once crawlers settled, they do not move for the rest of their lives and produce a white wax that covers their bodies (Beardsley and Gonzalez, 1975; Katovich et al., 2014; Kosztarab, 1996; Miller and Davidson, 2005; Rosen, 1990). The second generation hatches in late July or early in August (Katovich et al., 2014; Shour and Schuder, 1987).

Oleander scale is a tropical armored scale that reproduces yearround and needs 50 to $60 \mathrm{~d}$ to complete a generation. Both sexes feed principally on leaves. In shade house studies, eggs hatch in a period between 3 and $8 \mathrm{~d}$. The minimum preoviposition period of adult females was $23 \mathrm{~d}$. In contrast with pine needle scale, oleander scales lay their eggs in small groups over a period of up to $61 \mathrm{~d}$ (Miller and Davidson, 2005; Provencher et al., 2005).

Striped pine scale is a soft scale that produces three generations per year in Georgia where hatching starts in March (Clarke et al., 1989); whereas in Colorado, these produce one generation per year and start hatching in the beginning of June (Cooper and Cranshaw, 2004). After eggs hatch, females crawl and settle in the shoot, usually on the most recent growth, but older growth may be infested when population densities are high. Females may produce five eggs per hour and in excess of 1800 eggs during a 2 -week period (Clarke et al., 1989). In Indiana, there is one generation per year (personal observations).

Calico scale is a soft scale insect that produces one generation per year in the midwestern United States. Each adult female produces between 3700 and 4700 eggs in a single clutch, depending on host plant (Hubbard and Potter, 2005). Eggs normally hatch in the middle of May in Indiana. First instars crawl to the leaves where they settle and feed on leaf tissue. In the middle of July, calico scales molt to the second instar and remain on the leaves until the middle of September, when they move to the trunk and twigs to overwinter. From March to the middle of April, they develop into adults (Hubbard and Potter, 2005).

We conducted this study to determine efficacy of horticultural oil and insecticidal soap on two species each armored and soft scales under field and laboratory conditions at different life stages of scale insects.

\section{Material and methods}

REPRESENTATIVE INSECTICIDES. All experiments were conducted using insecticidal soap (Bonide ${ }^{\circledR}$; Novelty Manufacturing, Lancaster, PA) or a petroleum-based horticultural oil (Ultra-fine Oil; Whitmire Micro-Gen Research Laboratories, St. Louis, MO) both at a rate of $2 \mathrm{gal}$ of insecticide per 100 gal of water ( $2 \%$ solutions). All foliar applications of insecticides were applied to runoff.

Pine needle scale assays. One hundred and fifty-two scots pine trees (Pinus sylvestris) were obtained from a private nursery in West Olive, MI. Trees were $\approx 15$ inches tall, planted in the Meigs Research Farm, West Lafayette, IN, on 13 May 2014. Trees were infested by fastening $15-\mathrm{cm}$-long pine branches infested with pine needle scale in the egg stage on 26 May.

Biology of the first generation of pine needle scale was observed weekly. On 17 July, after the second generation began to hatch, a total of 16 trees were randomly selected and sprayed with either horticultural oil or water in a completely randomized design with eight replications. Applications were made with a 3 -gal sprayer (Solo, Newport News, VA) to the canopy until runoff, using $40 \mathrm{~mL}$ of solution about per plant, targeting young crawlers of the second generation of pine needle scale. A total of six infested needles (three from new growth and three from old growth) were randomly selected from 
each plant and taken to the laboratory to calculate mortality on 1 Aug. [ 15 $\mathrm{d}$ after treatment (DAT)] and 21 Aug. (35 DAT), respectively. At least 100 scales were examined per plant. Scale insects were considered dead if the body was dry and black or dark brown color. In contrast, scales were determined to be alive if it was yellowish to orange and excreted hemolymph when punctured.

In a second experiment on 20 Aug. 2015, a total of 15 trees from the original site that were infested with pine needle scale on 26 May 2014 , were used to test the effectiveness of horticultural oil, insecticidal soap, or water against adults in a completely randomized design with five replications. Application and evaluation of insect mortality were conducted as previously described.

Oleander scale assays. English ivy (Hedera helix) plants were used to test the efficacy of oil and soap against oleander scale insects. Plants grown without insecticides were purchased from Midwest Groundcovers (Chicago, IL) and transplanted into l-gal pots on 10 July 2015 . Trees were fertilized by mixing $19 \mathrm{~N}-2.6 \mathrm{P}-10.0 \mathrm{~K}$ slow-release fertilizer (Start-N-Grow 19-6-12; Ferti-lome, Bonham, TX) into the top $3 \mathrm{~cm}$ of soil at the time of planting and watered as needed for the rest of the season. Plants were maintained in a shade house at Throckmorton Purdue University Agricultural Farm, West Lafayette, IN.

Oleander scale was used because we had access to a colony growing on the fruit of butternut squash (Cucurbita moschata) that we could use to artificially infest host plants with crawlers of known age. Two separate experiments were made using oleander scale. The objective of the first experiment was to evaluate the effect of insecticidal soap and horticultural oil on first instar nymphs and adult females on intact plants. On 14 Sept., 21 english ivy plants were selected and taken to the laboratory for 1 week to infest them with the crawler stage of oleander scales. The plants were infested by brushing crawlers from a colony on butternut squash each day for $5 \mathrm{~d}$. After infestation, the plants were returned to the shade house and randomly assigned to one of the tree different treatments (water, horticultural oil, insecticidal soap) on 21 Sept. 2015 in a completely randomized design. A single insecticide application was made with a 3 -gal sprayer until runoff using $30 \mathrm{~mL}$ of solution about per plant, targeting first instar nymphs between 2 - and 7 -d old. At 15 and 21 DAT, five leaves infested with oleander scale were selected from each plant and taken to the laboratory to assess mortality. Under stereoscope, an ultra-fine needle $(0.5$ inch) was used to puncture each scale to determine if it was alive. Scale that expulsed hemolymph when punctured were considered alive. At least hundred scales were examined per plant. On 16 Nov. 2015, the study was repeated targeting adult females. Methodology was similar, but plants were grown under artificial light in the laboratory and insecticide application was delayed for $\approx 5$ weeks, when scales were mated adult females.

In the second experiment, efficacy of oil and soap were observed on crawler, first and second instar under laboratory conditions. We created a cohort of first (5- to 9-d old) and second instar (2l- to 26-d old) scales on 20 english ivy plants artificially infested from our squash colony for $4 \mathrm{~d}$ and placed under shadecloth. On 10 and 26 Sept. 2015 ( 5 and $7 \mathrm{~d}$ after infestations, respectively), 18 leaves infested with at least 20 oleander scale insects at each date were selected, taken to the laboratory, and placed into a $1.5-\mathrm{mL}$ microcentrifuge tube with water. Six leaves were randomly selected to be treated with horticultural oil, insecticidal soap, or water in a completely randomized design. About $2 \mathrm{~mL}$ was enough to cover the entire surface of a leaf using a $6-\mathrm{fl} \mathrm{oz}$ bottle sprayer (The Bottle Crew, Farmington Hills, MI). Mortality was observed 8 DAT as described previously.

Calico scale assays. To evaluate efficacy of horticultural oil and insecticidal soap on crawlers, twigs with swollen calico scale filled with eggs, were collected from naturally infested honeylocust trees (Gleditsia triacanthos) located in Carmel, IN. In addition, 18 leaves were collected from an 'Autumn Blaze' maple tree (Acer $\times$ freemannii) on the Purdue University campus, West Lafayette, IN. Each of 18 leaves were placed in separate petri dishes on top of cotton wool dampened with water and held at room temperature $\left(25^{\circ} \mathrm{C}\right)$ to keep leaves green. Thirty scale insects in the crawler stage were transferred from twigs to an excised maple leaf using a paint brush on 2 June 2015 . One day after infestation, petri dishes were randomly selected to be treated with horticultural oil, insecticidal soap, or water for a total of six replications in a completely randomized design. Products were applied with a 6-fl oz bottle sprayer until the leaf was covered completely, which was accomplished with $\approx 2 \mathrm{~mL}$ of solution. To assess mortality, each scale was visually examined 8 DAT under a stereoscope to determine if dead or alive. Dead scales were brown whereas live scales were yellow.

To evaluate effects of oil and soap on the first and second instars, a stand of infested honeylocust trees in Lafayette, IN, was used to collect scale insects for this study. For each experiment, 18 infested leaves were randomly selected. Four infested leaflets were excised from each leaf and placed in petri dishes on top of cotton wool dampened with water. Six of the 18 petri dishes were randomly chosen to be treated with horticultural oil, insecticidal soap, or water. Products were applied as described above. Mortality was assessed 8 DAT. Research was conducted on first instar nymphs on 29 June and 16 July and second instars nymph during 24 July 2015.

STRIPED PINE SCALE assays. Scotch pine trees were used to test the efficacy of oil against striped pine scale in the field. A total of 14 naturally infested trees with striped pine scales were selected in a Christmas tree farm in Fort Wayne, IN. Trees were $\approx 6$ years old and $\approx 2 \mathrm{~m}$ tall. On 26 June 2014, seven trees were randomly selected and sprayed with horticultural oil using a 3-gal sprayer. Application targeted young crawlers and ovipositing female of striped pine scales. Three twigs from each tree were collected from branches whose leaves were covered with sooty mold on 10 and 19 July (14 and 33 DAT). In the laboratory, three $12-\mathrm{cm}$ twig sections were used to assess mortality of young and adult scale insect on twigs. Live young scales were yellow whereas dead young scales were brown. Live adult scales were smooth whereas dead adult scales were shriveled and the color was faded brown.

ABBOT'S CORRECTED MORTALITY. Percent mortality on leaves treated 
with insecticide was corrected for mortality on the untreated leaves using the following formula.

$$
\frac{X-\Upsilon}{X} \times 100=\text { corrected mortality }
$$

where $X$ was the percent survival of the water control and $\Upsilon$ was the percent survival of the treatment (Abbott, 1925).

DATA ANALYSIs: Statistical analyses were performed using one way analysis of variance of all mortalities of each different scale insect species and life stages, using Statistica (version 12; StatSoft, Tulsa, OK). Before analysis by general linear model procedure, Shapiro-Wilk and Levenes' tests were conducted to determine normality and homogeneity of variance. If data did not meet these assumptions, arcsine transformation was performed. Scale insect mortality was the response variable whereas each treatment was an independent categorical variable. Means were compared with a Fisher's least significant difference.

\section{Results}

Pine needle scale. Mortality of first instar pine needle scale was significantly greater after application of horticultural oil than untreated control at $15(F=234.59 ; \mathrm{df}=1,14 ; P<0.001)$ and 35 DAT $(F=62.00 ; \mathrm{df}=1,14$; $P<0.001)$ showing corrected mortality of $84 \%$ and $80 \%$, respectively (Fig. lA). However, neither horticultural oil nor insecticidal soap was able to kill adult scales when compared with the untreated control $(F=1.84 ; \mathrm{df}=2$, $12 ; P=0.201$ ) (Fig. 1D).

Oleander scale. Application of horticultural oil or insecticidal soap killed significantly [at 15 DAT $(F=$ 99.72; $\mathrm{df}=2,18 ; P<0.001)$ and 21 DAT $(F=35.21 ; \mathrm{df}=2,18 ; P<$ $0.001)]$ oleander scale when targeted first instar stage under shade house conditions (Fig. 1B). Horticultural oil provided acceptable levels of $\mathrm{Ab}$ bot's corrected mortality with rates of
$90 \%$ at $15 \mathrm{DAT}$ and $81 \%$ at $21 \mathrm{DAT}$. Insecticidal soap was less effective against armored scales with only $54 \%$ and $23 \%$ corrected mortality at 15 and 21 DAT, respectively (Fig. 1B). Although both oil and soap killed significant numbers of adults $(F=8.49 ; \mathrm{df}=2,15 ; P=0.003)$, their corrected mortality was only $35 \%$ and 34\%, respectively (Fig. 1E).

Laboratory experiments showed similar results. When compared with untreated control, both horticultural oil and insecticidal soap showed higher mortality of oleander scale at the crawler stage [ 1 -d old, 8 DAT $(F=6.24 ; \mathrm{df}=2,15 ; P=0.011)]$ and first instar [5- to 9-d old, 8 DAT $(F=23.89 ; \mathrm{df}=2,15 ; P<0.001)]$. At the crawler stage, horticultural oil and insecticidal soap were statistically similar with corrected mortalities of $67 \%$ and $78 \%$, respectively (Fig. 2A). However, when settled first instars were targeted, horticultural oil $(45 \%)$ showed a greater reduction compared with the water control, followed by insecticidal soap
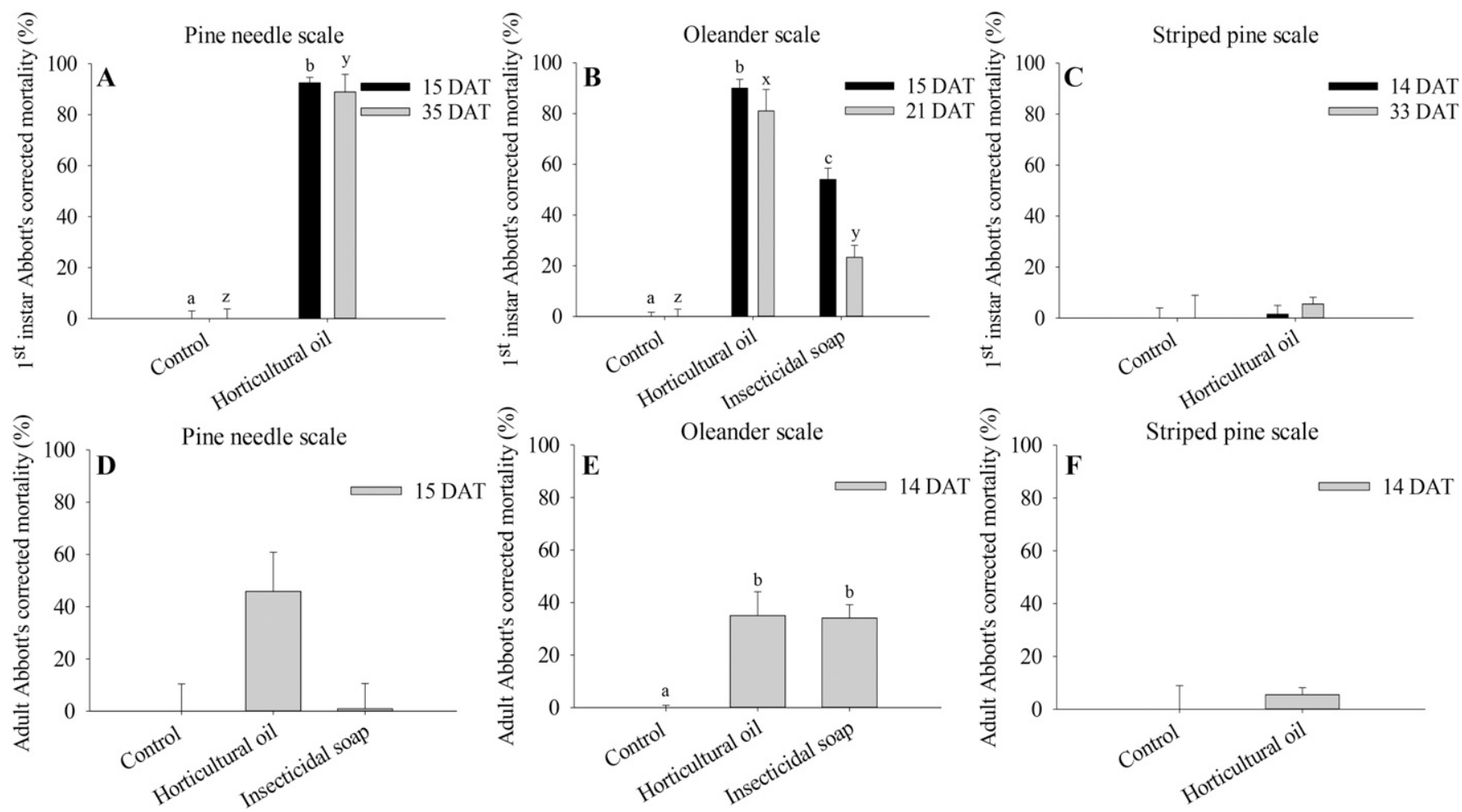

Fig. 1. Efficacy of horticultural oil (Ultra-fine Oil; Whitmire Micro-Gen Research Laboratories, Saint Louis, MO) and insecticidal soap (Bonide ${ }^{\circledR}$; Novelty Manufacturing, Lancaster, PA) on mortality of armored (pine needle and oleander) and soft (striped pine) scale insects on live plant hosts in field assays. Applications were made to immature stages of (A) pine needle scale, (B) oleander scale, and (C) striped pine scale. Applications were made to adult stages of (D) pine needle scale, $(E)$ oleander scale, and $(F)$ striped pine scale. Means $( \pm S E)$ followed by different lowercase letter are significantly different $(P<0.05)$ according to a Fisher's protected least significant difference. Letters a-c represented differences 14 or $15 \mathrm{~d}$ after treatment (DAT), whereas z-y represented differences 35 or 21 DAT. Abbot's corrected mortality was the mortality of the treatment corrected for observed mortality in the control. 
(18\%) (Fig. 2A). When second instars were targeted (2l-26 d old), there was no statistical differences in scale mortality [8 DAT $(F=2.88 ; \mathrm{df}=2$, $15 ; P=0.087)$ ] (Fig. 2A). However, corrected mortalities $38 \%$ and $32 \%$ by horticultural oil and insecticidal soap, respectively) were similar to mortalities when adults were targeted in the shade house study.

Calico scale. The capacity of horticultural oil and insecticidal soap to kill soft scales declined as scales aged. When applications targeted calico scale crawlers, mortality by insecticidal soap and horticultural oil was significantly higher than untreated control $[8$ DAT $(F=6.59 ; \mathrm{df}=2$, $27 ; P=0.005)]$. Horticultural oil and insecticidal soap showed Abbott's corrected mortality of $73 \%$ and 93\%, respectively (Fig. 2B). However, when insecticidal soap and horticultural were sprayed during settled first instar stage (29 June), only insecticidal soap (61\% reduction) had significantly fewer live scales than untreated control. Two weeks later, both insecticidal soap and horticultural oil failed to control calico scale when targeted late first [16 July $(F=$ $2.92 ; \mathrm{df}=2,15 ; P=0.084)]$ and second instar scales [24 July, 8 DAT $(F=0.15 ; \mathrm{df}=2,15 ; P=0.874)]$.

STRIPED PINE SCALE. Like calico scale, horticultural oil failed to control striped pine scale insect when targeting first instars [14 DAT $(F=$ $0.06 ; \mathrm{df}=1,12 ; P=0.801), 33$ DAT $(F=0.28 ; \mathrm{df}=1,12 ; P=0.606)]$ (Fig. lC) or the adult stage $(F=0.14 ; \mathrm{df}=$ $1,12 ; P=0.718)$ under field conditions (Fig. $1 \mathrm{~F}$ ).

\section{Discussion}

We found horticultural oil and insecticidal soap to be equally effective at controlling the crawler stages of both armored and soft scales. But, after scales had settled and begun to feed, horticultural oil was more effective than insecticidal soap against later stages of armored scales than soft scales. Conversely, insecticidal soap was more effective against later stages of soft scales than horticultural oil. The differential capacities of these materials to kill armored and soft scales over time may explain the lack of consistent results in the literature (Caldwell, 2003; Dreistadt, 1996; Hollingsworth, 2005; Phillips and Smith, 1963).

The results of this study suggest that the lipophilic nature of horticultural oil made it a more effective insecticide against later-stage armored scales than the more polar insecticidal soap. After armored scales settled, they made a covering formed of secreted wax filaments produced by pygidial wax glands (Miller and Davidson, 2005; Rosen, 1990). Wax
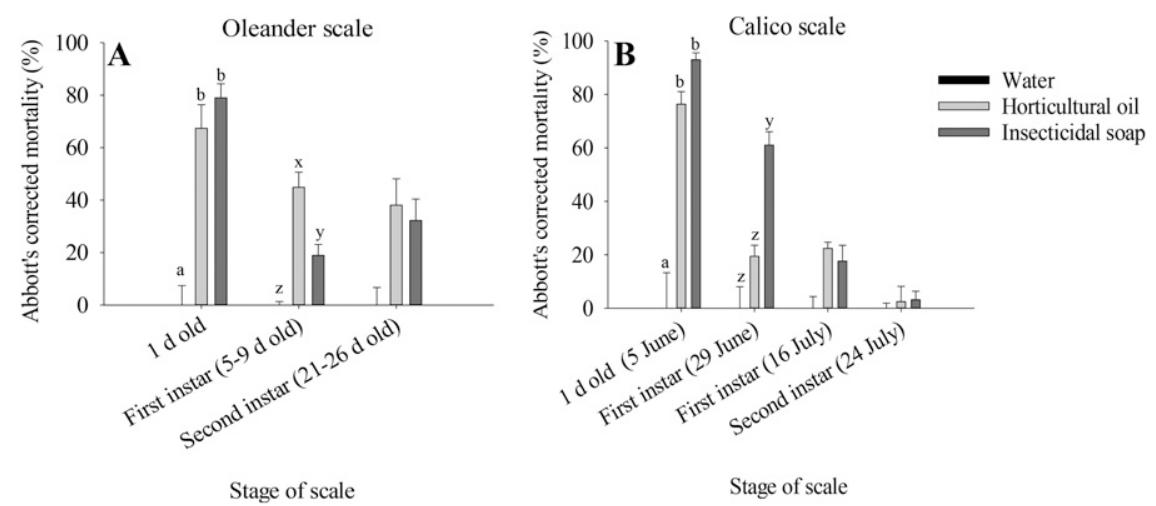

Fig. 2. Effects of applying horticultural oil (Ultra-fine Oil; Whitmire Micro-Gen Research Laboratories, Saint Louis, MO) and insecticidal soap (Bonide ${ }^{\circledR}$; Novelty Manufacturing, Lancaster, PA) on mortality when applied to leaves with different stages of armored (oleander) and soft (calico) scales in laboratory assays. (A) Oleander scales were treated $1 \mathrm{~d}$ after transferred to leaves, 5-9 d after settled, 21-26 d after settled. (B) Calico scales on treated $1 \mathrm{~d}$ after transferred to leaves, settled first instar, late first instar, and second instar nymph. Means $( \pm \mathrm{SE})$ followed by different lowercase letter are significantly different $(P<0.05)$ according to a Fisher's protected least significant difference. Letter a-c represented difference among 1 -d-old scales whereas $\mathrm{z}-\mathrm{y}$ represent differences among scales in the first instar stage. Abbot's corrected mortality was the mortality of the treatment corrected for observed mortality in the control. is about half of the composition of armored scale covers (Hackman, 1951), which facilitates the capacity of lipophilic insecticides such as horticultural oil to penetrate them. The penetration of liposoluble insecticides is positively correlated with the total amount of lipid in the insect integument (Pepper and Hastings, 1943; $\mathrm{Yu}, 2015)$. Our study showed that horticultural oil killed $>80 \%$ of both pine needle and oleander scale long after they had settled. These results and postulated mechanism would be consistent with much earlier studies of the efficacy of oil spray (Oronite Crystal) against different stages of California red scale (Ebeling, 1936). Horticultural oil did not control armored scale in the adult stage due to the continued accumulation of wax in the covers (Miller and Davidson, 2005; Rosen, 1990). We postulate that the wax cover of this stage of scale insects was thick enough to prevent solutions of $2 \%$ horticultural oil or insecticidal soap from penetrating it and reaching the scale body below. However, previous studies showed high rates of adult mortality resulting from applying a $4 \%$ solution of horticultural oil in the dormant season (Pless et al., 1995; Sadof and Sclar, 2000) suggesting that wax can be penetrated when more concentrated oil solutions are used.

Furthermore, our results suggest that insecticidal soap is a more effective insecticide against later stages of soft scale because it is less lipophilic than horticultural oil. Like armored scales, soft scales will cover their bodies with bulky materials, called a "test" after they settle. However, the wax fractions of soft scale tests are smaller than those of armored scale tests (Ben-Dov and Hodgson, 1997). In contrast, soft scales are also covered with honeydew, which is about $95 \%$ water and is composed mainly of amino acid and carbohydrates (Ben-Dov and Hodgson, 1997; Leroy et al., 2011; Völkl et al., 1999; Woodring et al., 2004). We postulate that the high concentration of aqueous material in the soft scale covers better facilitates the penetration of polar insecticidal soap. This is consistent with Olson and O'Brien (1963) who reported that insecticides with minimal hydrophilic properties (low partition coefficient) more readily penetrated the hydrophilic cuticle of american cockroach 
(Periplaneta americana) than nonpolar insecticides.

Our results showed that insecticidal soap maintains its efficacy after calico scale produced honeydew during the first instar, whereas horticultural oil failed to kill calico and striped pine scale insects at the same age. For this reason, we do not recommend horticultural oil to control soft scale insects despite its high capacity to kill 1-d-old crawlers. However, under natural conditions, it takes $\approx 19 \mathrm{~d}$ from the first to the last egg to hatch on calico scales (Hubbard and Potter, 2005 ) and over 1 month on striped pine scale (personal observations). As such, only a very small proportion of scale crawlers will be $1-\mathrm{d}$ old. The remaining life stages including second instars and adult stages, were unaffected by applications of either horticultural oil or insecticidal soap. We excluded pupilarial-scale insects that develop to adults within the sclerotized exuviae of their penultimate molt because they are relatively few species with this characteristic among the Coccoidea (Gullan and Williams, 2016).

In summary, our results help to explain the selectivity of horticultural oil and insecticidal soap in terms of the wax fraction on the integument of armored and soft scales. During the crawler stage, both soft and armored scales are susceptible to horticultural oil and insecticidal soap because of the absence of wax (Ben-Dov and Hodgson, 1997; Rosen, 1990). Later after they settle, the greater concentration of wax on the covers of armored scales repels the polar insecticidal soap but promotes penetration of the lipophilic horticultural oil. Conversely, the lower concentration of wax on the integument of soft scales repels the lipophilic horticultural oil and facilitates the infiltration of the more polar insecticidal soap. Last, results of this study suggest that generalizations about scale insects should be made with caution as the morphology of different scale groups can have profound effects on their management.

\section{Literature cited}

Abbott, W.S. 1925. A method of computing the effectiveness of an insecticide. J. Econ. Entomol. 18:265-267.

Addesso, K., A. Blalock, and P. O'Neal. 2016a. Japanese maple scale activity and management in field nursery production. J. Environ. Hort. 34:41-46.

Addesso, K., A. Blalock, and P. O'Neal. 2016b. Japanese maple scale in-field insecticide trials. 2 June 2017. <https://doi. org/10.1093/amt/tsw046>.

Agnello, A.M. 2002. Petroleum-derived spray oils: Chemistry, history, refining and formulation, p. 2-18. In: G.A.C. Beattie, D.M. Watson, M.L. Stevens, D.J. Rae, and R.N. Spooner-Hart (eds.). Spray oils beyond 2000. Univ. Western Sydney, Sydney, Australia.

Beardsley, J.W. and R.H. Gonzalez. 1975. The biology and ecology of armored scale. Annu. Rev. Entomol. 20:47-73.

Ben-Dov, Y. and C.J. Hodgson. 1997. Soft scale insects: Their biology, natural enemies and control. Vol. 7B. Elsevier Science, Amsterdam, The Netherlands.

Bostanian, N.J. and M. Akalach. 2004. The contact toxicity of indoxacarb and five other insecticides to Orius insidiosus (Hemiptera: Anthocoridae) and Aphidius colemani (Hymenoptera: Braconidae), beneficials used in the greenhouse industry. Pest Mgt. Sci. 601231-1236.

Bostanian, N.J. and M. Akalach. 2006 The effect of indoxacarb and five other insecticides on Phytoseiulus persimilis (Acari: Phytoseiidae), Amblyseius fallacis (Acari: Phytoseiidae) and nymphs of Orius insidiosus (Hemiptera: Anthocoridae). Pest Mgt. Sci. 62:334-339.

Caldwell, D.L. 2003. Cycad aulacaspis scale management trials, 2002. Arthropod Mgt. Tests. 2 June 2017. <https://doi. org/10.1093/amt/28.1.G34>.

Cating, R.A., M.A. Hoy, and A.J. Palmateer. 2010. Silwet L-77 improves the efficacy of horticultral oils for control of boisduval scale Diaspis boisduvalii (Hemiptera: Diaspididae) and the flat mite Tenuipalpus pacificus (Arachnida: Acari: Tenuipalpidae) on orchids. Fla. Entomol. 93:100-106.

Clarke, S.R., G.L. Debarr, and C.W. Berisford. 1989. The life history of Toumeyella pini (King) (Homoptera: Coccidae) in loblolly pine seed orchards in Georgia. Can. Entomol. 121:853-860.

Cooper, D. and W.S. Cranshaw. 2004. Seasonal biology and associated natural enemies of two Toumeyella spp in Colorado. J. Southwestern Entomol. 29:39-45.

Cranshaw, W. and B. Baxendale. 2005. Insect control: Horticultural oils. 2 June 2017. <http://extension.colostate. edu/topic-areas/insects/insectcontrol-horticultural-oils-5-569>.

Dickson, R.C. 1951. Construction of the scale covering of Aonidiella aurantii (Mask.). Ann. Entomol. Soc. Amer. 44:596-602.
Dreistadt, S.H. 1996. Citricola scale (Homoptera: Coccidae) abundance on chinese hackberry and scale control with spray oil or acephate trunk implants. J. Econ. Entomol. 89:481-487.

Ebeling, W. 1936. Effect of oil spray on california red scale at various stages of development. Hilgardia 10:95-125.

Frank, S.D. 2012. Reduced risk insecticides to control scale insects and protect natural enemies in the production and maintenance of urban landscape plants. Environ. Entomol. 41:377-386.

Gill, S. and M. Raupp. 1989. Control of azalea lace bug using insecticidal soap and neem. J. Amer. Rhododendron Soc. $43: 216-217$

Grafton-Cardwell, E.E. and C.A. Reagan. 1999. Citricola scale insecticide efficacy trial, 1997. 2 June 2017. <https://doi. org/10.1093/amt/24.1.D10>.

Gullan, P.J. and D.J. Williams. 2016. A new pupillarial scale insect (Hemiptera: Coccoidea: Eriococcidae) from Angophora in coastal New South Wales, Australia. Zootaxa 4117:85-100.

Hackman, R.H. 1951. The chemical composition of the wax of the white wax scale, Ceroplastes destructor (Newstead). Arch. Biochem. Biophys. 33:150-154.

Hashimoto, A., H. Yoshida, and K. Mukai. 1967. Studies on the lipids of coccids. Part IX. Separation and characterization of saturated and unsaturated wax esters from wax-shell lipids of Ceroplastes pseudoceriferus (Green). J. Agr. Biol. Chem. 41:498-505.

Heller, P.R., R.D. Lehman, and J. Witmer. 2004. Management of cryptomeria scale on fraser fir Christmas trees, 1998. 2 June 2017. <https://doi.org/ 10.1093/amt/29.1.G36>.

Hollingsworth, R.G. 2005. Limonene, a citrus extract, for control of mealybugs and scale insects. J. Econ. Entomol. 98:772-779.

Hubbard, J.L. and D.A. Potter. 2005. Life history and natural enemy associations of calico scale (Homoptera: Coccidae) in Kentucky. J. Econ. Entomol. 98:1202-1212.

Hubbard, J.L. and D.A. Potter. 2006. Managing calico scale (Hemiptera: Coccidae) infestations on landscape trees. Arboricult. Urban For. 32:138-147.

Katovich, S., D. McCullough, M. Ostry, J. O'Donnell, I. Munck, and C. Sadof. 2014. Christmas tree pest manual. 3rd ed. U.S. Dept. Agr., For. Serv. Bul. NA-FR-02-14.

Koehler, C.S., L.W. Barclay, and T.M. Kretchun. 1983. Soaps as insecticides. Calif. Agr. 37(9/10):11-12. 
Kosztarab, M. 1996. Scale insects of northeastern North America, identification, biology, and distribution. Virginia Museum of Natural History, Martinsville, VA.

Leroy, P.D., B. Wathelet, A. Sabri, F. Francis, F.J. Verheggen, Q. Capella, P. Thonart, and E. Haubruge. 2011. Aphidhost plant interactions: Does aphid honeydew exactly reflect the host plant amino acid composition? Arthropod-Plant Interact. 5:193-199.

Miller, D.R. and J.A. Davidson. 2005. Armored scale insect pests of trees and shrubs (Hemiptera: Diaspididae). Cornell Univ. Press, Ithaca, NY.

Miller, F.D. 1989. The use of horticultural oils and insecticidal soaps for control of insect pests of amenity plants. J. Arboricult. 15:257-262.

Oetting, R.D. and J.G. Latimer. 1995. Effects of soaps, oils, and plant growth regulators (PGRs) on Neoseiulus cucumeris (Oudemans) and PGRs on Orius insidiosus(Say). J. Agr. Entomol. 12:101109.

Olson, W.P. and R.D. O'Brien. 1963. The relation between physical properties and penetration of solutes into the cockroach cuticle. J. Insect Physiol. 9:777786.

Pepper, J.H. and E. Hastings. 1943. Age variations in exoskeletal composition of the sugar beet webworm and their possible effect on membrane permeability. J. Econ. Entomol. 36:633-634.

Phillips, J.H.H. and E.H. Smith. 1963. Further studies on susceptibility of european fruit lecanium, Lecanium corni Bouché, to oil. J. Econ. Entomol. 56:175-180.

Philpott, D.E., S.H. Berlocher, R.F. Mitchell, and L.M. Hanks. 2009. Molecular validation of a morphological character for distinguishing between the armored scale insects Chionaspis pinifoliae and Chionaspis heterophyllae
(Hemiptera: Diaspididae). Ann. Entomol. Soc. Amer. 102:381-385.

Pless, C.D., D.E. Deyton, and C.E. Sams. 1995. Control of San Jose scale, terrapin scale, and European red mite on dormant fruit trees with soybean oil. HortScience 30:94-97.

Provencher, L.M., G.E. Morse, A.R. Weeks, and B.B. Normark. 2005. Parthenogenesis in the Aspidiotus nerii complex (Hemiptera: Diaspididae): A single origin of a worldwide, polyphagous lineage associated with Cardinium bacteria. Ann. Entomol. Soc. Amer. 98:629635.

Raupp, M.J., J.J. Holmes, C. Sadof, P. Shrewsbury, and J.A. Davidson. 2001. Effects of cover sprays and residual pesticides on scale insects and natural enemies in urban forests. J. Arboricult. 27:203214.

Rebek, E.J. and C.S. Sadof. 2003. Effects of pesticide applications on the euonymus scale (Homoptera: Diaspididae) and its parasitoid, Encarsia citrina (Hymenoptera: Aphelinidae). J. Econ. Entomol. 96:446-452.

Reinking, R.B. 1964. Brown soft scale in Texas 1. Proc. Florida State Hort. Soc. 77:70-73.

Rosen, D. 1990. Armored scale insects: Their biology, natural enemies and control. Vol. 4A. Elsevier Sci. Publ., Amsterdam, The Netherlands.

Sadof, C.S. and D.C. Sclar. 2000. Effects of horticultural oil and foliar-or soilapplied systemic insecticides on euonymus scale in pachysandra. J. Arboricult. 26:120-125.

Sewald, N. and H.D. Jakubke. 2002. Peptides: Chemistry and biology. Wiley, Weinheim, Germany.

Shour, M.H. and D.L. Schuder. 1987. Host range and geographic distribution of Chionaspis heterophyllae Cooley and C. pinifoliae (Fitch) (Homoptera: Diaspididae). Indiana Acad. Sci. 96:297304.
Smith, S.F. and V.A. Krischik. 2000. Effects of biorational pesticides on four coccinellid species (Coleoptera: Coccinellidae) having potential as biological control agents in interiorscapes. J. Econ. Entomol. 93:732-736.

Tamaki, Y. and S. Kawai. 1969. X-ray diffraction studies on waxy covering of scale insects (Homoptera: Coccoidea). Appl. Entomol. Zool. 4:79-86.

Tremblay, É., A. Belanger, M. Brosseau, and G. Boivin. 2008. Toxicity and sublethal effects of an insecticidal soap on Aphidius colemani (Hymenoptera: Braconidae). Pest Mgt. Sci. 64:249-254.

Völkl, W., J. Woodring, M. Fischer, M.W. Lorenz, and K.H. Hoffmann. 1999. Antaphid mutualisms: The impact of honeydew production and honeydew sugar composition on ant preferences. Oecologia 118:483-491.

Weinzierl, R.A. 2000. Botanical insecticides, soaps, and oils, p. 101-118. In: J.E. Rechcigl and N.A. Rechcigl (eds.). Biological and biotechnological control of insect pests. CRC Press, Boca Raton, FL.

Woodring, J., R. Wiedemann, M.K. Fischer, K.H. Hoffmann, and W. Völkl. 2004. Honeydew amino acids in relation to sugars and their role in the establishment of ant-attendance hierarchy in eight species of aphids feeding on tansy (Tanacetum vulgare). Physiol. Entomol. 29:311-319.

Xiao, Y., R. Mao, L. Singleton, and S. Arthurs. 2016. Evaluation of reduced-risk insecticides for armored scales (Hemiptera: Diaspididae) infesting ornamental plants 1. J. Agr. Urban Entomol. 32:71-90.

$\mathrm{Yu}$, S.J. 2015. The toxicology and biochemistry of insecticides. 2nd ed. CRC Press, Boca Raton, FL. 